The Science of Psychopathy and Some Strategies for Moving Forward

Nicholas Kavish

The University of Nebraska Medical Center

Joshua D. Miller

The University of Georgia

Brian B. Boutwell

The University of Mississippi

University of Mississippi Medical Center 
Individuals with psychopathic traits commit disproportionate amounts of crime (Hare, 1996), cost billions annually (Kiehl \& Hoffman, 2011), and often create havoc in their social orbit (Smith \& Lilienfeld, 2013). Given its ripple effects, the decades long explosion of psychopathy research is unsurprising. For reasons we discuss, though, it is similarly unsurprising that certain foundational questions remain unresolved. Why do psychopathic traits vary and how do they develop over the life-course? Are the traits stable, or malleable, and in either case what are the driving factors? Infusing it all are practical considerations about data and the requirements for producing answers. Relative to psychopathy, the study of normative personality has produced a deep reservoir of insight on these core issues, both empirical and theoretical (Briley \& Tucker-Drob, 2017). We argue that by importing parts of their knowledge along with certain research designs, psychopathy research can take a rapid leap forward. Psychopathy: A (Very) Brief Primer

The general characterization of psychopathy as a constellation of interpersonal, affective, and behavioural manifestations, the full litany of which is tightly associated with externalizing and antisocial outcomes, has reached virtual consensus across fields (e.g., Cleckley, 1941/1976; Hare, 1991/2003; Lilienfeld \& Andrews, 1996). Where disagreement remains is around the efforts to organize the relevant traits into specific domains, ranging in number from two to six, with every psychometric development accompanied by rigorous discussion (Cooke et al., 2012; Cooke \& Michie, 2001; Neumann et al., 2005; Patrick et al., 2009). A common presumption, however, is that psychopathy is a construct that can be understood separately from other more normative aspects of cognition and personality (e.g., Cleckley, 1941/1976).

Rapidly gaining traction is the argument that the construct is better understood as a configuration of common personality traits calibrated at extreme levels, with particular reliance 
on the Five Factor Model (FFM). The FFM (measured often with NEO PI-R; Costa \& McCrae, 1992) includes the well-known domains of Openness, Conscientiousness, Extraversion, Agreeableness, and Neuroticism, each of which is underlain by six specific facets (e.g., Agreeableness: trust, straightforwardness, altruism, compliance, modesty, and tendermindedness). Expert ratings (Miller et al., 2001), translations of existing measures (e.g., the Psychopathy Checklist-Revised; Widiger \& Lynam, 1998), and meta-analytic evidence (Decuyper et al., 2009; Lynam \& Derefinko, 2006) all point to a psychopathy profile comprising low scores on Agreeableness (e.g., trust, compliance, altruism) and Conscientiousness (e.g., dutifulness, self-discipline, deliberation) and a mix of high and low scores on facets of Neuroticism (e.g., high: angry hostility, impulsiveness; low: anxiety, depression) and Extraversion (e.g., high: assertiveness, excitement seeking; low: warmth, positive emotions). Early evidence for this formulation was promising (Miller et al., 2001; Miller \& Lynam, 2003) and led to the creation of a FFM-based psychopathy measure - the Elemental Psychopathy Assessment (EPA; Lynam et al., 2011). Subsequent factor analytic work (Few et al., 2013) suggested that the EPA exhibits factors corresponding to four of the five FFM domains strongly linked to psychopathy (all but Openness).

Some additional conceptualizations warrant mentioning and represent mostly, more modern, trait-based conceptualizations, including the triarchic model of psychopathy (TriPM; Patrick et al., 2009). The TriPM focuses on Boldness, Meanness, and Disinhibition (see Sleep et al., 2019 for a meta-analytic review). The individual domains are described as neurobehavioral in nature, yet they also align closely with FFM domains. Hyatt and colleagues (2020), in fact, quantified similarities between FFM domains and a TriPM measure and found enough overlap to confidently assert that: “...unaltered traits from one can be considered excellent representations 
of the other" (p. 72). If psychopathy is best understood as a configuration of personality traits at pathological levels, then personality research becomes all the more relevant (e.g., Vachon et al., 2013). In alignment with these arguments, clinical scholars have incorporated a view of personality disorders (including psychopathy) as representing pathological levels of normative personality dimensions in major diagnostic nosologies, including the alternative model of personality disorder in the Diagnostic and Statistical Model of Mental Disorders $-5^{\text {th }}$ Edition (DSM-5; APA, 2013) and the International Classification of Diseases - 11 (World Health Organization, 2019).

\section{Empirical Insights}

Sources of Variance. Personality and psychopathy vary for heritable and environmental reasons (Willoughby et al., 2022; Bezdjian et al., 2011; Blonigen et al., 2005; Larsson et al., 2006; Polderman et al., 2014; Tucker-Drob \& Briley, 2019; Tuvblad et al., 2014). In a kind of paradox, personality development can be understood as being both malleable and stable, depending on which frames of the life-course and the level or type of personality being examined (domain vs. facet, adaptive vs. maladaptive traits) (Barnes et al., 2017; Bleidorn et al., 2022; Roberts \& Caspi, 2001). Rank-order stability builds from $0.35-0.50$ in infancy to $0.65-0.90$ by around age 30 (Barnes \& Boutwell, 2012; Ferguson, 2010; Roberts \& DelVecchio, 2000; Tucker-Drob \& Briley, 2019), with less evidence for a continued rise in stability beyond age 25 (Bleidorn et al., 2022). Meta-analysis of longitudinal studies suggests greater stability at the domain level and on measures of adaptive personality traits, relative to facet-level and maladaptive traits (Bleidorn et al., 2022).

Analogous evidence for psychopathy is sparse. We revisit this below, but for now what does exist suggests that PCL psychopathy scores over a two-year period were less stable in 
adolescence $(r=0.31)$ than adulthood ( $r=0.71$; Cauffman et al., 2016). Heritability estimates were around $50 \%$ for rank order stability across individuals in 'callous-unemotional (CU) traits' - a construct related to psychopathy, particularly the domain of meanness or antagonism (see Figure 1 in Hyde \& Dotterer, 2022 for a depiction of the overlap)—spanning approximately 5-year periods (Moore et al., 2019). Henry and colleagues (2018) reported evidence that genetic factors at age 7 continued to captured portions of variation in CU traits at ages 9, 10, and 12 years old. No evidence emerged, though, of novel genetic effects at ages 9 and 10 and any remaining influences were captured by age-specific non-shared factors (Henry et al., 2018), though, perhaps complicated by having different effect according to genetic predisposition.

The Developmental Dynamics of Personality. Work on longitudinal research on personality suggests that heritable influences peak in childhood (approximately $70 \%$ of variance explained) and decrease in adolescence (approximately 50\%) and adulthood (about 35\%; Briley \& Tucker-Drob, 2014), an interesting contrast to the steadily increasing heritability of cognitive functioning across the life-course (see Deary et al., 2009; Plomin \& Deary, 2015). Nonshared influence rises from around 30\% in infancy to around 65\% in adulthood (Briley \& Tucker-Drob, 2014). The correlation of personality traits taken at two timepoints during infancy $(\sim 0.35)$ seems best explained by genetic factors, but the increasing stability across time (from $\sim 0.35$ to $\sim 0.70$ ) appears most attributable to nonshared effects. Heritable influences on stability appear static with age and increasing stability seems primarily linked to nonshared factors (Briley \& Tucker-Drob, 2014; Briley et al., 2019; Tucker-Drob \& Briley, 2019). The specific nonshared factors implicated remains obscure, but one place to start is with the idea of proactive personenvironment transactions, in which individuals actively seek out environments that suit their traits (a point we return to below, see also Caspi \& Roberts, 2001). In such a scenario, more 
antisocial adolescents embed themselves in peer groups which further reinforce such behaviors (thereby increasing the stability of the relevant traits).

\section{Thinking Theoretically}

Accompanying the empirical work is the challenge to make sense of it. Personality science has some established insight to draw on, starting with the genetic set point and moving set point perspectives (Tucker-Drob \& Briley, 2019). Both involve heritable and environmental factors. Heritable factors locate us in a general sense on dimensional traits (Rowe, 2001; TuckerDrob \& Briley, 2019). Fluctuations around "set points" are expected, in the wake traumatic events, for example (Hammen, 2005), followed by returns to typical trait-levels. Favourable evidence comes from the study of twins reared together, and identical twins reared apart, whose personalities correlate $(\sim 0.50)$ at just below the average stability of personality in adulthood (Bouchard et al., 1990; Krämer \& Rodgers, 2019). The moving set point differs, but only slightly, by invoking "trajectories" as opposed to set points (see Tucker-Drob \& Briley, 2019). The distinction better accommodates varying age-graded personality trajectories, as well as evidence of relevant, but transient environmental effects. Differing slightly, the genetic maturation hypothesis, posits that genetic effects can differ across time (Lacourse et al., 2014). All versions ultimately struggle to explain decreasing heritability and increasing environmental influences across development (Tucker-Drob \& Briley, 2019).

The random walk explanation suggests that the changes in personality trait levels over time are best conceived of as random departures from the levels just prior (Tucker-Drob \& Briley, 2019). Experiences alter personality and these changes compound across time. The perspective seems better equipped to explain large nonshared effects over time, increased between-person variation in personality in childhood and adolescence, and is consistent with 
increasing rank-order stability (Tucker-Drob \& Briley, 2019). It struggles to mesh with consistent evidence that variation across personality constructs is partly attributable to genetic variation, which is to say that it is "heritable", nor does it easily accommodate the existence of the self-selection effects described just below (Tucker-Drob \& Briley, 2019).

The final perspectives are "learning" curves with decay and selecting/sorting experiences (Tucker-Drob \& Briley, 2019). The first captures instances when environments moderate heritable influences on personality (i.e., gene-environment interaction or GxE) (Barnes et al., 2014; Purcell, 2002). The sorting perspective refers to a type of selection bias or geneenvironment correlation (rGE; Beaver et al., 2009; Rutter \& Silberg, 2002; Scarr and McCartney, 1983; Tanksley et al., 2020). Evidence of rGE suggests that relatively minor genetic differences might produce substantive between-person variation in personality via both selection into certain environments combined with a tendency to evoke certain reactions and experiences once there (Scarr and McCartney, 1983; Tucker-Drob \& Briley, 2019). Debating which theoretical lens is most appropriate is beyond our scope and Tucker-Drob and Briley (2019) do an excellent job on that front. The point is that these concepts are as relevant for psychopathy as they are for personality.

\section{Methodological Considerations}

One key facet of our discussion has been implicit, and we now want to make it explicit. Not all forms of data are capable of offering insight to our focal questions. Carving variance into heritable and environmental components, while also examining developmental patterns, requires longitudinal sibling data (see Willoughby et al., 2022). Kandler et al. (2012) offer a prototypical example in their analysis of a multi-wave twin study exploring reciprocal influences of life events and FFM traits. The relevant hallmarks are multiple sources of measurement, multiple 
waves of data permitting estimates of stability and change, and of course, siblings. It should be encouraging to know that there is some precedent for this already in the field, meaning the challenge is not starting from scratch but building on what has been done (see Bezdjian et al., 2011; Blonigen et al., 2005; Larsson et al., 2006; Tuvblad et al., 2014).

What Can Be Said Currently?

Now we can revisit work mentioned earlier that is more directly relevant to psychopathy. Blonigen et al. (2006) reported rank-order stability (corrected ' $r$ 's $>0.60$ ) in both interpersonalaffective and social deviance traits between ages 17 and 24. A divergence in trajectories emerged between two dimensions of psychopathy, with fearless dominance remaining stable and impulsive antisocial traits declining over time. Stability was largely heritable, with changes tied mainly to non-shared factors. To a lesser degree, novel genetic influences, less relevant at time 1, emerged as potentially important (Blonigen et al., 2006).

Henry et al. (2018) found that heritable influences on callous-unemotional traits at age 7 persisted in explaining associations with trait scores at ages 9, 10, and 12. Novel genetic influences emerged at ages 9 and 10. Non-shared factors were age-specific and shared factors had no effects. At the moment, Blonigen et al. (2006) and Henry et al. (2018) point to a moving set point interpretation, meaning that heritable factors calibrate mean trait levels and environmental factors drive fluctuations. Only provisional assessments are appropriate now because the evidence base is so thin. Yet despite a limited body of evidence, this discussion makes no claims of being exhaustive. We intend this only as an illustration of applying some relevant thinking from personality science to scholarship on the construct of psychopathy (see Hyde \& Dotterer, 2022).

\section{Concluding Thoughts}


The concept of psychopathy is complex and key debates are in no danger of rapid resolution (Miller \& Lynam, 2012; Skeem \& Cooke, 2010). Knowledge accumulation is iterative and slow, but insights and tools from personality science can help to accelerate the process (see Hyde and Dotterer, 2022 on CU traits). No one need start from scratch, however, should they desire to adopt some or all of our suggestions. Collaborative teams formed nationally and internationally, comprised of both clinicians and academic researchers (even individuals with various lived experiences with psychopathy; e.g., https://psychopathyis.org/) can capitalize on a rich array of resources. The availability and ease of access to large, nationally representative family samples, replete with psychometrically sound measurement should offer no small measure of encouragement (Barnes \& Boutwell, 2013; Willoughby et al., 2022).

Our modest list of suggestions seems all the more sensible given the evidence that 'psychopathy' is likely better understood as extreme deviations along dimensions of normative personality. This particular point implies something larger and more sweeping, though, and it merits space in our conclusion. Personalities can change through cognitive therapies (Roberts et al., 2021) and via volitional efforts (e.g., Hudson \& Fraley, 2015), to mention but two mechanisms. By extension, 'psychopathic' traits may likewise be open to psycho-therapeutic intervention, and indeed evidence for changes in trait levels themselves (see Hawes et al., 2014), as well as in the maladaptive behaviors linked to the traits (e.g., violent behavior; Skeem et al., 2002) already exists. As our insight about the origins and development of psychopathic traits continues to grow it will accelerate the already promising efforts to alleviate suffering, both for individuals scoring high on psychopathic traits as well as those who find themselves left in their wake. 


\section{References}

American Psychiatric Association (2013). Diagnostic and Statistical Manual of Mental Disorders. Fifth Edition. American Psychiatric Association; Washington, DC.

Barnes, J. C., \& Boutwell, B. B. (2012). On the relationship of past to future involvement in crime and delinquency: A behavior genetic analysis. Journal of Criminal Justice, 40(1), 94-102.

Barnes, J. C., \& Boutwell, B. B. (2013). A demonstration of the generalizability of twin-based research on antisocial behavior. Behavior Genetics, 43(2), 120-131.

Barnes, J. C., Wright, J. P., Boutwell, B. B., Schwartz, J. A., Connolly, E. J., Nedelec, J. L., \& Beaver, K. M. (2014). Demonstrating the validity of twin research in criminology. Criminology, 52(4), 588-626.

Barnes, J. C., El Sayed, S. A., TenEyck, M., Nedelec, J. L., Connolly, E. J., Schwartz, J. A., ... \& Anderson, N. E. (2017). Estimating relative stability in developmental research: A critique of modern approaches and a novel method. Journal of quantitative criminology, 33(2), 319-346.

Beaver, K. M., Eagle Schutt, J., Boutwell, B. B., Ratchford, M., Roberts, K., \& Barnes, J. C. (2009). Genetic and environmental influences on levels of self-control and delinquent peer affiliation: Results from a longitudinal sample of adolescent twins. Criminal Justice and Behavior, 36(1), 41-60.

Bezdjian, S., Raine, A., Baker, L. A., \& Lynam, D. R. (2011). Psychopathic personality in children: genetic and environmental contributions. Psychological Medicine, 41(3), 589600. 
Bleidorn, W., Schwaba, T., Zheng, A., Hopwood, C., Sosa, S., Roberts, B., \& Briley, D. (2022). Personality stability and change: A meta-analysis of longitudinal studies. Psychological Bulletin. doi: 10.1037/bul0000365.

Blonigen, D. M., Hicks, B. M., Krueger, R. F., Patrick, C. J., \& Iacono, W. G. (2005). Psychopathic personality traits: Heritability and genetic overlap with internalizing and externalizing psychopathology. Psychological medicine, 35(5), 637-648.

Blonigen, D. M., Hicks, B. M., Krueger, R. F., Patrick, C. J., \& Iacono, W. G. (2006). Continuity and change in psychopathic traits as measured via normal-range personality: A longitudinal-biometric study. Journal of Abnormal Psychology, 115(1), 85-95.

Bouchard, T. J., Lykken, D. T., McGue, M., Segal, N. L., \& Tellegen, A. (1990). Sources of human psychological differences: The Minnesota study of twins reared apart. Science, 250(4978), 223-228.

Briley, D. A., Livengood, J., Derringer, J., Tucker-Drob, E. M., Fraley, R. C., \& Roberts, B. W. (2019). Interpreting behavior genetic models: seven developmental processes to understand. Behavior Genetics, 49(2), 196-210.

Briley, D. A., \& Tucker-Drob, E. M. (2014). Genetic and environmental continuity in personality development: A meta-analysis. Psychological Bulletin, 140(5), 1303-1331.

Briley, D. A., \& Tucker-Drob, E. M. (2017). Comparing the developmental genetics of cognition and personality over the life span. Journal of Personality, 85(1), 51-64.

Caspi, A., \& Roberts, B. W. (2001). Personality development across the life course: The argument for change and continuity. Psychological inquiry, 12(2), 49-66. 
Cauffman, E., Skeem, J., Dmitrieva, J., \& Cavanagh, C. (2016). Comparing the stability of psychopathy scores in adolescents versus adults: How often is "fledgling psychopathy" misdiagnosed?. Psychology, Public Policy, and Law, 22(1), 77-91.

Cleckley, H. (1941/1976). The mask of sanity. St Louis, MO: Mosby.

Cooke, D. J., Hart, S. D., Logan, C., \& Michie, C. (2012). Explicating the construct of psychopathy: Development and validation of a conceptual model, the Comprehensive Assessment of Psychopathic Personality (CAPP). International Journal of Forensic Mental Health, 11(4), 242-252.

Cooke, D. J., \& Michie, C. (2001). Refining the construct of psychopathy: Towards a hierarchical model. Psychological Assessment, 13(2), 171-188.

Costa, P. T., Jr., \& McCrae, R. R. (1992). NEO Personality Inventory-Revised (NEO-PI-R) and NEO Five-Factor Inventory (NEO-FFI) professional manual. Odessa, FL: Psychological Assessment Resources.

Deary, I. J., Johnson, W., \& Houlihan, L. M. (2009). Genetic foundations of human intelligence. Human genetics, 126(1), 215-232.

Decuyper, M., De Pauw, S., De Fruyt, F., De Bolle, M., \& De Clercq, B. J. (2009). A metaanalysis of psychopathy-, antisocial PD-and FFM associations. European Journal of Personality, 23(7), 531-565.

Ferguson, C. J. (2010). A meta-analysis of normal and disordered personality across the life span. Journal of Personality and Social Psychology, 98(4), 659-667.

Few, L. R., Miller, J. D., \& Lynam, D. R. (2013). An examination of the factor structure of the Elemental Psychopathy Assessment. Personality Disorders: Theory, Research, and Treatment, 4(3), 247-253. 
International Classification of Diseases, Eleventh Revision (ICD-11) (2019). World Health Organization.

Hammen, C. (2005). Stress and depression. Annual Review of Clinical Psychology, 1, 293-319.

Hare, R.D. (1991/2003). The Hare Psychopathy Checklist-Revised. Toronto, Ontario: MultiHealth Systems.

Hare, R. D. (1996). Psychopathy: A clinical construct whose time has come. Criminal Justice and Behavior, 23(1), 25-54.

Hawes, D. J., Price, M. J., \& Dadds, M. R. (2014). Callous-unemotional traits and the treatment of conduct problems in childhood and adolescence: A comprehensive review. Clinical child and family psychology review, 17(3), 248-267.

Henry, J., Dionne, G., Viding, E., Petitclerc, A., Feng, B., Vitaro, F., ... \& Boivin, M. (2018). A longitudinal twin study of callous-unemotional traits during childhood. Journal of Abnormal Psychology, 127(4), 374-384.

Hudson, N. W., \& Fraley, R. C. (2015). Volitional personality trait change: Can people choose to change their personality traits?. Journal of personality and social psychology, 109(3), 490-507.

Hyatt, C. S., Crowe, M. L., Lynam, D. R., \& Miller, J. D. (2020). Components of the Triarchic Model of Psychopathy and the Five-Factor Model domains share largely overlapping nomological networks. Assessment, 27(1), 72-88.

Hyde, L. W., \& Dotterer, H. L. (2022). The Nature and Nurture of Callous-Unemotional Traits. Current Directions in Psychological Science, 09637214221121302. 
Kandler, C., Bleidorn, W., Riemann, R., Angleitner, A., \& Spinath, F. M. (2012). Life events as environmental states and genetic traits and the role of personality: A longitudinal twin study. Behavior Genetics, 42(1), 57-72.

Kiehl, K. A., \& Hoffman, M. B. (2011). The criminal psychopath: History, neuroscience, treatment, and economics. Jurimetrics, 51, 355-397.

Krämer, M. D., \& Rodgers, J. L. (2019). The impact of having children on domain-specific life satisfaction: A quasi-experimental longitudinal investigation using the Socio-Economic Panel (SOEP) data. Journal of Personality and Social Psychology. Advance online publication. https://doi.org/10.1037/pspp0000279

Lacourse, E., Boivin, M., Brendgen, M., Petitclerc, A., Girard, A., Vitaro, F., ... \& Tremblay, R. E. (2014). A longitudinal twin study of physical aggression during early childhood: evidence for a developmentally dynamic genome. Psychological Medicine, 44(12), 26172627.

Larsson, H., Andershed, H., \& Lichtenstein, P. (2006a). A genetic factor explains most of the variation in the psychopathic personality. Journal of Abnormal Psychology, 115, 221230.

Lilienfeld, S. O., \& Andrews, B. P. (1996). Development and preliminary validation of a selfreport measure of psychopathic personality traits in noncriminal populations. Journal of Personality Assessment, 66, 488-524.

Lynam, D. R., \& Derefinko, K. J. (2006). Psychopathy and personality. In C. J. Patrick (Ed.), Handbook of psychopathy (pp. 133-155). New York: Guilford Press.

Lynam, D. R., Gaughan, E. T., Miller, J. D., Miller, D. J., Mullins-Sweatt, S., \& Widiger, T. A. (2011). Assessing the basic traits associated with psychopathy: Development and 
validation of the Elemental Psychopathy Assessment. Psychological Assessment, 23(1), $108-124$.

Mann, F. D., Briley, D. A., Tucker-Drob, E. M., \& Harden, K. P. (2015). A behavioral genetic analysis of callous-unemotional traits and Big Five personality in adolescence. Journal of Abnormal Psychology, 124(4), 982-993.

Miller, J. D., \& Lynam, D. R. (2003). Psychopathy and the five-factor model of personality: A replication and extension. Journal of Personality Assessment, 81(2), 168-178.

Miller, J. D., \& Lynam, D. R. (2012). An examination of the Psychopathic Personality Inventory's nomological network: A meta-analytic review. Personality Disorders: Theory, Research, and Treatment, 3(3), 305-326.

Miller, J. D., Lynam, D. R., Widiger, T. A., \& Leukefeld, C. (2001). Personality disorders as extreme variants of common personality dimensions: Can the five factor model adequately represent psychopathy?. Journal of Personality, 69(2), 253-276.

Moore, A. A., Blair, R. J., Hettema, J. M., \& Roberson-Nay, R. (2019). The genetic underpinnings of callous-unemotional traits: A systematic research review. Neuroscience \& Biobehavioral Reviews, 100, 85-97.

Patrick, C. J., Fowles, D. C., \& Krueger, R. F. (2009). Triarchic conceptualization of psychopathy: Developmental origins of disinhibition, boldness, and meanness. Development and Psychopathology, 21(3), 913-938.

Plomin, R., \& Deary, I. J. (2015). Genetics and intelligence differences: five special findings. Molecular psychiatry, 20(1), 98-108. 
Polderman, T. J., Benyamin, B., De Leeuw, C. A., Sullivan, P. F., Van Bochoven, A., Visscher, P. M., \& Posthuma, D. (2015). Meta-analysis of the heritability of human traits based on fifty years of twin studies. Nature genetics, 47(7), 702-709.

Purcell, S. (2002). Variance components models for gene-environment interaction in twin analysis. Twin Research and Human Genetics, 5(6), 554-571.

Purcell, S., \& Sham, P. (2002). Variance components models for gene-environment interaction in quantitative trait locus linkage analysis. Twin Research and Human Genetics, 5(6), $572-576$.

Roberts, B. W., \& Caspi, A. (2001). Personality Development and the Person-Situation Debate: It's Déjà Vu All Over Again. Psychological Inquiry, 12(2), 104-109.

Roberts, B. W., \& DelVecchio, W. F. (2000). The rank-order consistency of personality traits from childhood to old age: A quantitative review of longitudinal studies. Psychological Bulletin, 126(1), 3-25.

Roberts, B. W., Luo, J., Briley, D. A., Chow, P. I., Su, R., \& Hill, P. L. (2017). A systematic review of personality trait change through intervention. Psychological Bulletin, 143(2), $117-.141$

Rowe, D. C. (2001). Do people make environments or do environments make people?. Annals of the New York Academy of Sciences, 935(1), 62-74.

Rutter, M., \& Silberg, J. (2002). Gene-environment interplay in relation to emotional and behavioral disturbance. Annual Review of Psychology, 53(1), 463-490.

Scarr, S., \& McCartney, K. (1983). How people make their own environments: A theory of genotype $\rightarrow$ environment effects. Child development, 424-435. 
Skeem, J. L., \& Cooke, D. J. (2010). Is criminal behavior a central component of psychopathy? Conceptual directions for resolving the debate. Psychological Assessment, 22(2), 433445.

Skeem, J. L., Monahan, J., \& Mulvey, E. P. (2002). Psychopathy, treatment involvement, and subsequent violence among civil psychiatric patients. Law and human behavior, 26(6), $577-603$.

Sleep, C. E., Weiss, B., Lynam, D. R., \& Miller, J. D. (2019). An examination of the Triarchic Model of psychopathy's nomological network: A meta-analytic review. Clinical Psychology Review, 71, 1-26.

Smith, S. F., \& Lilienfeld, S. O. (2013). Psychopathy in the workplace: The knowns and unknowns. Aggression and Violent Behavior, 18(2), 204-218.

Tanksley, P. T., Barnes, J. C., Boutwell, B. B., Arseneault, L., Caspi, A., Danese, A., ... \& Moffitt, T. E. (2020). Identifying psychological pathways to polyvictimization: evidence from a longitudinal cohort study of twins from the UK. Journal of Experimental Criminology, 1-31.

Tucker-Drob, E. M., \& Briley, D. A. (2019). Theoretical concepts in the genetics of personality development. In D. P. McAdams, R. L. Shiner, \& J. L. Tackett (Eds.), The handbook of personality development. New York, NY: Guilford Press, p. 40-58.

Tuvblad, C., Bezdjian, S., Raine, A., \& Baker, L. A. (2014). The heritability of psychopathic personality in 14- to 15-year-old twins: A multirater, multimeasure approach. Psychological Assessment, 26(3), 704-716. 
Vachon, D. D., Lynam, D. R., Widiger, T. A., Miller, J. D., McCrae, R. R., \& Costa, P. T. (2013). Basic traits predict the prevalence of personality disorder across the life span: The example of psychopathy. Psychological Science, 24(5), 698-705.

Widiger, T.A., \& Lynam, D.R. (1998). Psychopathy as a variant of common personality traits: Implications for diagnosis, etiology, and pathology. In T. Millon (Ed.), (pp. 171-187). New York: Guilford.

Willoughby, E., T. Polderman, and B.B. Boutwell (2022) Behavioural Genetics Methods. Forthcoming at Nature Reviews Methods Primers. 